\title{
Komentarze datacyjne do Andrzeja Bańkowskiego Etymologicznego stownika języka polskiego
}

To, co zostało zrobione, poucza jak zrobić coś lepszego. Ralph Waldo EMERSON

Słow a kluc ze: etymologia polska, datowanie i redatacja haseł, dobór źródeł tekstowych poświadczających najstarsze użycia

Wymieniony w tytule niniejszego szkicu słownik to wciąż nieukończone dzieło, niemniej praca już na podstawie dwu dotychczas wydanych tomów może być uznana moim zdaniem - m.in. ze względu na obfity nowy materiał hasłowy, nieobecny w istniejących ogólnych słownikach etymologicznych języka polskiego - za niezwykle cenną, inspirującą publikację, która w istotny sposób wzbogaca skromny wciąż co do liczebności zbiór tych słowników.

Niedawno interesującą analizę krytyczną jednego, zwartego fragmentu ESJP, mianowicie opracowania wybranych rusycyzmów, przedstawił Marek Iwanowski (2011), celem mojego artykułu jest ogólny, sondażowy ogląd informacji datacyjnej, chronologizacyjnej zawartej w ESJP; interesuje mnie tutaj jedynie okres od początku XIX w. do współczesności.

Jako utrwalająca się, pozytywną nowość polskiej techniki leksykografii diachronicznej podkreślić należy, że ESJP wybija w tekście artykułów ha- 
słowych datę „narodzin” wyrazu czy wyrażenia na samym początku. Są to z reguły daty roczne, rzadziej okresy. Autor stosuje przejrzyste zapisy skrótowe, „symbolokształtne”; np. $X X-1$ oznacza okres 1. poł. XX w., $X I X-2$ to 2. poł. w. XIX itp. Zakładać należy, iż ka żdy autor czuje się w pełni odpowiedzialny za każdy znaczący (relewantny) segment tekstu swojego słownika etymologicznego, w tym za datowanie haseł.

Niżej przedstawiam ,centurię” wybranych z ESJP jednostek wraz z komentarzami datacyjnymi do nich.

\section{ALUZJA XIX-2}

Taka datacja jest niejasna. Czy Autorowi ESJP idzie o wyraz w pisowni współczesnej tylko? Wówczas rzeczywiście za SWarsz. można by mówić o zaistnieniu, przynajmniej leksykograficznym, tego rzeczownika dopiero w 2. poł. XIX w., bo jego tom I ukazał się jako introligatorska całość z datą 1900, a zeszyty (jeszcze przed oprawą) wychodziły bodajże od $1898 \mathrm{r}$. W SWil. jest jeszcze alluzja, zamiast aluzja, a znacznie wcześniej, w SJPL alluzya (1807).

\section{ANEKTOWAĆ XX-1}

Ten czasownik zauważył Oczyszciciel (1891), odsyła do: annektować, pod którym umieścił rozwlekłe objaśnienie 'złączyć, przyłączyć, przywłaszczać, przywłaszczyć, wcielić; także nabyć co samowolnie bez zapłaty’.

\section{ARTYSTYCZNY 1894}

Źródła tej datacji nie znam (hasło ma SWarsz., 1900), ale dysponuję dwoma wcześniejszymi świadectwami. Jest to DNPS (1844), w którym translandowi artistisch przyporządkowany został translat: artystyczny, a także SPRAST (1873), z parą translatów: артистический, артистский. Ważna - jako świadectwo życia, rozpowszechnienia wyrazu - jest obecność redatowanego przymiotnika w słowniku preskryptywnym; zob. Oczyszciciel (1891) z objaśnieniem ‘sztuczny, doskonale wyrobiony’.

\section{BANAL 1950}

Jak czytamy w ESJP, dorobione do banalny, ale kiedy faktycznie? Ten derywat wsteczny odnotował w 1939 ESWO, z definicją 'powiedzenie oklepane'. 


\section{BARIERA 1861}

Data wg SWil.; hasło w pisowni barjera. Wcześniej por. DNPS (1844): Barriere baryera.

\section{BIUROKRACJA 1861}

Jest to data ze SWil. Nieco wcześniejszą ${ }^{1}$ zob. w bezcennym Dykcjonarzu (1859) w pisowni współczesnej, z objaśnieniem 'przewaga, wpływ urzędników'.

\section{CHLUPOTAĆ 1884}

Autor przywołuje przy tych „narodzinach” Henryka Sienkiewicza. Kłóci się ta informacja z dawnym zapisem w DPNS (1835: 69): Chlupać, und als Frequent. Chlupotać.

\section{CIĄGNIK 1950}

Ten, jak informuje autor ESJP, „sztuczny nowotwór przekładowy” znany był jednak i używany już przed drugą wojną światową. Należy wiedzieć, że ma go w hasłowniku SIJP (1929). Tamże występuje on w ważnej, bo metaleksykograficznej sferze, jako definiens (s.v. traktor).

\section{DOKTRYNA 1861}

Obecna w SWil., ale ma Dykcjonarz (1859) z definicją 'racjonalna czegoś teoria; zbiór zasad politycznych lub religijnych na rozumienie tylko osnutych, pozorno-naukowy systemat'.

\section{DOPASOWAĆ 1900}

Data wzięta ewidentnie ze SWarsz., przejęta - by tak rzec - mechanicznie, z karty tytułowej I tomu. Należało się wczytać w dokumentację cytatową, umieszczoną w artykule, gdzie wskazany został J. I. Kraszewski i B. Prus. Zastanawia jednak stare (1836!) poświadczenie tego germanizmu, w NSPR, z dobrze dobranym tanslatem приладить.

1 Przesunięcie datacji hasła wstecz zaledwie o rok czy dwa uważam - inaczej niż Tadeusz Piotrowski (2006: 74) - za istotne, ważne tak samo, jak przesunięcia o lat 20 czy kilka wieków. Polemikę z zaskakującym stanowiskiem T. Piotrowskiego przedstawię gdzie indziej. 


\section{DOSLOWNY XIX-2}

Jednak stanowczo XIX-1; por. DPNS (1835) z translatem: wörtlich (oraz ilustracją: dosłowne tłumaczenie eine wörtliche Uebersetzung).

\section{DRASKA 1952}

Powyższą datę wywiódł Bańkowski z cytatu zamieszczonego w SJPDor. Podważę to datowanie cytatem prasowym: ,[...] potrafił przenieść [...] przez rewizję kilka sztuk [papierosów], parę zapałek i draskę” („Prosto z Mostu”, Warszawa, nr 15 z 14 IV 1935 r., s. 2).

\section{DRASTYCZNY 1874}

SJPDor. ma najstarszy cytat właśnie z tego roku. Por. jednak DNPS (1844): drastisch med. drastyczny, t. i. mocno działaiący.

\section{DREN 1900}

Datę, wziętą ze SWarsz., obala nie(d)oceniony Oczyszciciel (1891), a przesuwa jeszcze dalej Dykcjonarz (1859) z objaśnieniem 'in. sqczek, nazwa rur glinianych, używanych do osuszenia gruntów i łąk wilgotnych'.

DRENAŻ ok. 1900

ESJP przywołuje tu B. Prusa. Ma Oczyszciciel (1891) z zamiennikami 'osącznik, osuszalnik, osusznik'.

\section{DRENOWAĆ 1900}

Data za SWarsz. Potępia Oczyszciciel (1891), proponując 'osączać, osączyć, odsączać, osuszać, osuszyć. Wcześniej uchwycił SPRAST (1873): дpeнировать, осушать поля дренами.

\section{DRES 1955}

W SJPDor. są dwa cytaty: 1952 (nb.) i 1955 r. W ESWO (1939) ten anglicyzm jest w pisowni dress (z definicją 'ubiór, strój; w sporcie ubiór zawodników o barwach klubowych lub reprezentacyjnych’).

\section{DUBLOWAĆ 1861}

Data wg SWil. Zna Dykcjonarz (1859), a jeszcze dawniej DPNS (1835), w parze ze zdublować. 


\section{DUDZIARZ 1900}

Tę datę, wzbogaconą przez autora ESJP informacją, że wyraz wystąpił najpierw u H. Sienkiewicza, trzeba zestawić z obecnością danego derywatu w Oczyszcicielu (1891).

\section{DYRYGENT 1900}

Ma SWarsz.; por. Oczyszciciel (1891).

\section{DYSKUSJA 1861}

$\mathrm{Z}$ tą pisownią ma SWil., ale i też Dykcjonarz (1859). W pisowni dyskusya por. w DSWP (1856) s.v. DISCUSSIONE.

\section{DYSKUTANT 1950}

Datowanie za SJPDor., gdzie są 3 cytaty (dwa prasowe, jeden książkowy), najstarszy właśnie z 1950. Zob. jednak w PПC (1933) ciąg translatów pod спорщик: kłótnik, sprzecznik, spornik, dyskutant.

\section{ELEKTRYFIKOWAĆ 1956}

Kolejna datacja ograniczona do tego, co zawiera SJPDor. (jeden jedyny cytat, prasowy). Sprzed ćwierćwiecza zob. ПРC z tymże czasownikiem. Notabene, redaktor owego słownika podkreślił w przedmowie, że jego zespół korzystał nie tylko ze słowników języka polskiego, lecz także ze współczesnej [mu] literatury i prasy polskiej.

\section{ELIMINACJA 1861}

Datowanie wg SWil., obala Dykcjonarz (1859).

\section{EMANCYPOWAĆ 1861}

Datacja według SWil., ma Dykcjonarz (1859), ze słowników przekładowych - DNPS (1844), s.v. emancipiren.

\section{EMBRION 1861}

Rok za SWil., tu w pisowni embrjon. Por. dużo wcześniejsze poświadczenie słownikowe w DPNS (1835) z hasłem w pisowni mianownika embryo. 


\section{EMERYT 1861}

Tu też wystarczył autorowi ESJP SWil. Zob. jednak w DNPS (1844) artykuł Emerit emeryt; wysłużony.

\section{EMERYTURA 1861}

Zob. SWil. z definicją dokładnie taką, jaka była już znana, z Dykcjonarza (1859): 'pensja wysłużona'. Sporo wcześniej, nieco inaczej, zob. w DNPS (1844) artykuł Emeritur z ciągiem translatowym: emerytura, wysłużona pensya.

\section{EMISJA 1861}

Czyli za (niezastapionym dla ESJP) SWil., tu w pisowni emissja. Por. Dykcjonarz (1859), hasło emissja 'puszczenie w kurs, wypuszczenie' Listy zastawne drugiéj emissji.

\section{EMOCJA 1861}

Za SWil., w nim definiens 'wzruszenie'. W Dykcjonarzu (1859) to też tylko 'wzruszenie'.

\section{EMPIRYCZNY XIX-2}

Jest kilka świadectw słownikowych nakazujących bezwzględnie poprawkę: XIX-1. Ma to hasło filozoficzne m.in. DPNS (1835).

ENCYKLIKA 1861

Data za SWil. Zob. nieco wcześniejszy Dykcjonarz (1859).

ENIGMATYCZNY 1861

Por. dokładnie jak wyżej.

\section{ENTUZJAZM 1861}

Data za SWil., ale jej przesunięcie większe; por. w DPNS (1835) ortogram entuzyazm $z$ odesłaniem do zapal.

\section{EPIGON 1900}

Datacja wg SWarsz. Należy się zastanowić nad hasłem epignon w Oczyszcicielu (1891). 


\section{EPIZOD 1861}

Za SWil. W DNPS (1844) zob.: Episode epizod; ustęp.

\section{EROTYCZNY 1861}

Oczywiście za SWil. Ma Dykcjonarz (1859) z objaśnieniem 'miłosny'. Zwracam uwagę, że jeszcze wcześniej DNPS (1844) w artykule erotisch dał informację: erotyczny, miłosny, np. pieśń.

\section{ESKALATOR 1952}

Data za SJPDor., z cytatem z czasopisma. Zob. hasło w SPR (1949).

\section{ETYCZNY 1861}

Datę ze SWil. podważa nieco Dykcjonarz (1859) z ciekawą formułą 'o nauce moralnéj traktujący'. Hasło ma już DPNS (1835).

\section{EWAKUOWAĆ 1861}

Data ESJP zaczerpnięta ze SWil. Znacznie wcześniejsze jest świadectwo DNPS (1844) z artykułem: evacuiren ewakuować.

\section{FETYSZ 1861}

Za SWil.: 'bałwan; bożek Negrów'. W Dykcjonarzu (1859) to 'przedmiot czci u Murzynów, bałwan'.

\section{FINEZJA 1898}

Przy tej dacie ESJP powołuje się na J. Weyssenhoffa ze znaczeniem sparafrazowanym jednowyrazowo: 'subtelność'. Znowu wcześniejszy okazuje się Oczyszciciel (1891); por. w nim artykuł: Finesa, finezya, fr. przebiegłość, przenikliwość, chytrość, podstęp, wybieg, wymysł.

\section{FLOTYLLA 1861}

Autorowi ESJP znowu wystarcza SWil. Por. Dykcjonarz (1859): 'mała flota, z kilku okrętów lub statków złożona'.

\section{FOKA 1861}

Data za SWil., ale wyraz opisał Dykcjonarz (1859): (Phoca) zool. zwierzę ssące, należące do rzędu płetwonogich. 


\section{FORMACJA 1861}

Datacja ze SWil. Ma Dykcjonarz (1859), a jeszcze nieco wcześniej zob. w DSWP (1856) artykuł FORMAZIONE formacya, ukształcenie, utworzenie.

\section{FORMALISTA 1861}

ESJP za SWil. Redatuje najdalej (według moich aktualnych danych) DPNS (1835), z którego warto przytoczyć frazę-translat: der die Formalitäten pünktlich beobachtet.

\section{FORMALIZOWAĆ 1861}

ESJP za SWil. Wcześniej odnotował „z życia” Dykcjonarz (1859).

\section{FORT 1861}

ESJP pod tą datą notuje tylko użycie z zakresu wojskowości, tzn. opiera się na danych SWil., nie wiedząc nic o opisie wyrazu w Dykcjonarzu (1859).

\section{FORTEPIAN 1861}

Data ze SWil. (tu hasło w pisowni fortepjan). Ciekawe, że CDEP (1849) notuje graficzną postać fortepian (w artykule PIANO).

\section{FRAPOWAĆ 1861}

Poprawić można ESJP, wiernie datujący za SWil., dzięki Dykcjonarzowi (1859).

GAGAT 1861

Komentarz jak wyżej.

GAMBIT 1861

Komentarz jak wyżej.

\section{GANG 1957}

Tę datę ESJP odnosi do znaczenia 'zespół współdziałających przestępców' (ujęcie semantyczne SJPDor. jest zbliżone: 'grupa ludzi zorganizowanych dla wspólnej działalności przestępczej; banda, szajka'). Historia tego znaczenia sięga jednak międzywojnia, co wykazała Halina Koneczna (1936/37: 169). 
GARDZIOLKO 1861

Data za SWil. Tymczasem CDPE (1851) odnotował w artykule GARDZIEL także deminutyw GARDZIOŁKO!

\section{GATUNKOWY XIX-2}

Jasno na XIX-1 wskazuje jednak obecność tego hasła w DPNS (1835).

\section{GESZEFT 1890}

Ustalona w ESJP data nie jest właściwa, skoro Bogusław Nowowiejski odnotował (1996: 285) starsze użycie prasowe, w „Gazecie Warszawskiej” (1880, nr 156, s. 4).

\section{GOJ 1861}

Data wg SWil. Ujął jednak Dykcjonarz (1859).

\section{GRAFICZNY 1900}

Data za SWarsz. Przymiotnik znacznie wcześniej zanotował, m.in., DSWP (1856), ten jako translat przy translandzie GRAFICO.

\section{GRAWEROWAĆ 1900}

Data za SWarsz. (tu brak cytatu) i SJPDor. (tu najstarszy cytat zaczerpnięty z prasy 1900 r.). Oczyszciciel (1891) zanotował tylko postać grawierować.

\section{GULASZ 1861}

Data za SWil. W Dykcjonarzu (1859) por.: '(z węg.) sztuka mięsa na sposób węgierski (potrawa)'.

\section{GWARDZISTA 1861}

Za SWil., tuż przed nim Dykcjonarz (1859), a wyraźnie wcześniej zob. to hasło w DPNS (1835), z odesłaniem do gwardyak.

\section{HASZYSZ 1861}

Datacja A. Bańkowskiego wg SWil. Wcześniejsze świadectwo, z ŹW (1858), warto przytoczyć w całości, z powodu jego atrakcyjnej szaty językowej: „HASZYSZ trawa zwiędła, siano w ogóle, a w szczególności mówi się o liściach konopi indyjskich, które suszą i używają dla żucia i do fajki za- 
miast tytuniu. [...] w Persii, Egipcie, Syryi i w innych krajach wschodu: ziarna i liście haszysza, gotowane i przyrządzone z sezamem i cukrem w pastylki, bardzo są poszukiwane u ludów tamecznych, robią też z tego likier mocny, który sprawuje rodzaj szaleństwa i bardzo zgubne skutki”.

\section{HEKTAR 1861}

Tak za SWil., ale tuż przed nim jest Dykcjonarz (1859).

\section{HIPOPOTAM 1861}

$\mathrm{Z}$ tą datą mamy ortogram hippopotam (w SWil.). Pisownia uproszczona, dzisiejsza, figuruje w CDEP (1849): HYPPOPOTAMUS hipopotam, zwierzę żyjące w Nilu.

\section{HIPOTEZA 1861}

Data za SWil. Formę-translat hypoteza ma m.in. CDEP (1849), w artykule HYPOTHESIS.

\section{HODOWLA 1870}

Przy tej dacie ESJP wspomina jako źródło W. Pola i zaznacza, że słowo jest częste dopiero od XX-1. Istnieją też jednak dość liczne świadectwa użycia z całego XIX w. Najstarsze z moich znalezisk to CDEP (1849), w którym pod BREEDING wypisany został taki oto ciąg translatów: płodzenie, chów, hodowla bydła, wychowanie.

\section{HOKEJ 1954}

Data z SJPDor., w którym są dwa cytaty, oba z prasy, oba z 1954 r. Nie należy jednak zapominać o pisowni oryginalnej powyższego anglicyzmu; artykuł hockey ma E-XX (1938). Nawiasem mówiąc, w tymże artykule wskazanej encyklopedii poświadczona została pisownia współczesna - hokej, w nazwie własnej (instytucjonimie) Polski Zwiazek Hokeja na lodzie.

\section{JEDNORZĘDOWY 1861}

Za SWil. Ma wszakże DPNS (1835).

\section{JOD 1861}

I to ze SWil., ale zob. w DSWP (1856) artykuł: IODIO Chim. jod, jodyna. 


\section{KACYK XIX-2}

Por. DPNS (1835) z frazą-translatem: der Kazike (bei den Amerikanischen Wilden).

\section{KADM 1861}

Rocznik wg SWil. Na pewno niewłaściwy, za młody.

\section{KAMUFLAŻ 1946}

Data przyjęta zgodnie z cytatem występującym w SJPDor. Zapożyczenie jest jednak przedwojenne, por. SWO-A (1935).

KANALIZACJA 1861

Data ze SWil. Por. jednak Dykcjonarz (1859) z takąż pisownią.

\section{KANCELISTA 1861}

Data ESJP ewidentnie za SWil. W pisowni jeszcze nie uproszczonej (kancellista) zna NSPR (1836: 55).

\section{KANISTER 1961}

SJPDor. ma ,goły” artykuł, pozbawiony cytatów dokumentacyjnych. Wskazana w ESJP data pochodzi z nieznanego mi źródła, być może jest to jakiś słownik wyrazów obcych. Nb. znaczenie 'zbiornik, bak na benzynę' zarejestrował SWO-R (1958). ESWO (1939) ujął rzecz tak: 'blaszane, szczelne pudełko do herbaty, prochu itp.' Niewykluczona jest przedwojenność zapożyczenia kanister w znaczeniu 'zbiornik, bak na benzynę'.

\section{KAROSERIA 1954}

W SJPDor. z dwoma cytatami: 1941 (!) i 1954. Właśnie tę drugą datę wskazuje ESJP, choć np. ma to hasło SO-JT (1951). Nadmienię jeszcze, z pewnym skrępowaniem, że hasło karoserja ma SIJP (1929), a hasło karoseria - SJPLehr (1938).

\section{KULTYWACJA 1954}

Jest to data za cytatem z K. Brandysa w SJPDor. Rzeczownik znany jednak wcześniej, ma go ESWO (1939). 


\section{KULUARY 1948}

Datę tę potwierdzają dane SJPDor. Opis ESWO (1939) wskazuje już jednak na użycie przenośne.

\section{LECZNICTWO XIX-2}

Dane SWarsz. wskazują na datę 1902. Świadectw(a) datacji obecnej ESJP nie znam, ale musi ona być odrzucona ze względu na znalezione przeze mnie świadectwo z Józefa Majera (1849: 22).

\section{LOKOMOTYWA 1857}

Informacja zaczerpnięta z SJPDor., w którym najstarszy cytat jest opatrzony tą właśnie datą. Moje świadectwo jest zaledwie o rok wcześniejsze; zob. DSWP: LOCOMOTIVA lokomotywa, parowóz.

\section{LORA 1950}

Ustalenie ESJP za SJPDor. Por. jednak informację w ESWO (1939), która umożliwia mi przesunięcie jednostki do zasobów polszczyzny przedwojennej.

\section{LOTNISKOWIEC 1945}

Datacja własna Autora ESJP (w SJPDor. z cytatu wynika r. 1955). Ważna źródłoznawczo EW ma w t. 5 (1936) cały artykuł na temat lotniskowców.

\section{LAMIGŁÓWKA 1890}

Datacja ESJP wyprowadzona prawdopodobnie z danych SJPDor. Wcześniej zob. CDPE (1851).

\section{LOWCA XIX-2}

Prawda jest inna: XIX-1. Por. w CDEP (1849) artykuł: HUNTSMAN łowca, myśliwiec; łowczy.

\section{MASZYNERIA 1961}

Por. jednak postać maszyneryja, w związku wyrazowym maszyneryja sktadowa w SPRAST (1873).

\section{MUSKULARNY 1861}

Data za SWil. Przymiotnik odnotował nieco wcześniej Dykcjonarz (1859). 


\section{MUSKULATURA 1861}

Data za SWil. Rzeczownik odnotował nieco wcześniej Dykcjonarz (1859).

\section{MUTRA 1861}

Datacja ESJP za SWil. Ten termin techniczny uchwycił przed „Wileńskim” Dykcjonarz (1859).

\section{NARKOMAN 1948}

Nie wiem, skąd data w ESJP; w SJPDor. wyraz jest w cytacie z 1950 r. Ten rzeczownik osobowy ukuty został jednak przed drugą wojną światową; zarejestrował go i trafnie opisał SJPLehr (1939), ważne, niestety nieukończone (jak ESJP) dzieło polskiej leksykografii.

\section{NARKOTYK 1861}

Data za SWil. Lepiej było wziąć do ręki Dykcjonarz (1859); ma ciekawą formułę definicyjną: 'lekarstwo sprawiające uśpienie, odurzenie, upojenie v. uśmierzenie'.

\section{OSPRZĘT 1951}

W SJPDor. derywat został udokumentowany dwoma cytatami, z 1951 i... z 1950 r. Jest to wedle jędrnego określenia autora ESJP bękart z rosyjskiego оснастка. Poczęty jednak sporo wcześniej, skoro zarejestrował go SIJP (1929).

OTOMANA 1904

Data SWar. Wcześniejszy jest Oczyszciciel (1891).

PACHTOWAĆ 1908

Datacja ESJP - jeśli można tak powiedzieć - odruchowa, według danych SWarsz. Por. koniecznie Oczyszciciel (1891) z formułą 'dzierżawić, wynająć wynajmować'.

\section{PIERWSZYZNA 1859}

Nie znam źródła tej datacji, mam wcześniejszą: DPNS (1836); ciekawostką jest odnotowanie przez ten słownik przekładowy zwrotu nie pierwszyzna to iети. 


\section{PLANDEKA 1908}

To datacja wg SWarsz. Znacznie wcześniej zanotował SPRAST (1873), $\mathrm{z}$ translatem чехол.

\section{PRECYZOWAĆ 1932}

W SJPDor. z 4 cyt.: 1951, 1954, 1936, 1934. Istotna jest obecność danego czasownika w siatce haseł SIJP (1929), z definicją 'udokładniać, usubtelniać'.

\section{PRODUKOWAĆ 1861}

ESJP zaznacza, że ma na względzie znaczenie 'wytwarzać' i wskazuje, za SJPDor., źródło: SWil. Por. wszakże nieznany mu NSPR (1836) z adekwatnym translatem производить.

\section{PRZECIER 1954}

W artykule SJPDor. występują 3 cytaty, najstarszy jest właśnie z 1954 r. Por. przecież broszurkę anonimową Przetwory (1948: 29) z pięknym objaśnieniem: „Przecier jest to półprzetwór, powstały z miazgi, przetartej przez przetak lub cedzik i następnie utrwalony”.

\section{PRZYCHODNIA 1954}

Tu ESJP posłużył się (niezbyt starannie) dokumentacją cytatową zawartą w SJPDor. Wyraz znany wcześniej, także według danych tegoż SJPDor. Por. również źródło wykorzystywane przeze mnie: SO-JT (1951).

\section{PSEUDONIM 1861}

Nb. Dykcjonarz (1859) z formułą 'autor piszący pod zmyślonem imieniem'.

PULSOWAĆ 1904.

Germanizm ten poświadcza SO-K (1903).

\section{PUMEKS 1861}

Data ESJP za SWil. W pisowni niespolszczonej występuje w NSPR (1836); pumex dokumentuje też Dykcjonarz (1859).

Moje aktualne rozeznanie (re)datacyjne w obrębie słownictwa nowopolskiego wykracza dość mocno poza opisaną wyżej ,pękatą” centurię. Na 
pewno można będzie dokładnie udokumentować wcześniejsze niż wskazane w ESJP wystapienia jednostek takich np. wyrazów - ,pierwszych z brzegu” (w większości obcych z pochodzenia) - jak: aneks, anilana, antysemita, aparatura, archaiczny, czasochłonny, dynamo, dyskryminować, elokwentny, emitować, fikuśny, grzejnik, jełczeć, kabaczek, landryny, laser, literować, lodołamacz, lotnisko, lajza, muzealny, muzykować, ostaniec, nachalny, pasmanteria, pierwowzór, plomba, plombować, poczekalnia, podest, prognoza, propan, protokolant, prymitywny, przedplata, przeszukać, pseudonim, psiak, psocić, psychiatra, psychiczny, psychika, psycholog, pulower, puma.

Oczywiście także te dokumentacje, które przedstawiłem w artykule jako poprawki do datacyj ESJP, nie zamykają sprawy rechronologizacji materiałów tego słownika. Niejedno hasło uda się przedatować wstecz o rok, dwa czy więcej. Na datacje ostateczne w większości wypadków jest jeszcze za wcześnie. Przybliża te ustalenia ostateczne - dla okresu nowopolskiego - wysiłek naukowy Piotra Wierzchonia, twórcy oryginalnej i nadzwyczaj wydajnej, w sensie pozytywnych skutków poznawczych dla praktyki badawczej, teorii lingwochronologizacji (por. Wierzchoń 2008). Jest P. Wierzchoń jedynym jak dotychczas i, przypuszczam, jeszcze na dłuższe lata wyjątkowym lingwistą, który potrafi czerpać dane leksykograficzne niezbędne do uwalniania od dezinformacji nagromadzonej w szokujących ilościach w literaturze poświęconej tzw. nowemu słownictwu polskiemu (por. Wawrzyńczyk 2011) w sposób „hurtowy” z bibliotek cyfrowych (por. Wierzchoń 2010-2011). Zaistnienie w Polsce ponad $50^{2}$ bibliotek cyfrowych to wydarzenie, z którego rangi nie zdaje sobie sprawy wciąż większość badaczy polonistów.

Kilka uwag podsumowująco-metodologicznych. [1 $\left.{ }^{\circ}\right]$ Datowanie haseł w ESJP ujawnia nadmierne przywiązanie jego Autora do słowników narodowych języka polskiego jako źródeł informacji chronologicznej. Niezbędne jest sięganie do jak największej liczby istniejących słowników: objaśniających, ortograficznych, technicznych itp., także słowników przekładowych. Wielu pozycji tego typu najwyraźniej w zestawie źródeł datacyjnych ESJP brak. $\left[2^{\circ}\right]$ Wartość dokumentacyjna słowników ogólnych języka polskiego, tych najbardziej znanych i najpowszechniej używanych (od „Lindego" do „Dubisza”), dla prac nad indeksem chronologicznym wyrazów polskich (por.

\footnotetext{
${ }^{2}$ Powstają dalsze.
} 
Piotrowski 2006) jest wtórna względem dokumentacji pozaleksykograficznej, jaką czerpać należy z publikacji niesłownikowych, z literatury pięknej, naukowej, publicystycznej itp., z czasopism, prasy itp. Zresztą same słowniki, zarówno te uznane za narodowe, jak i te mniejsze, nie są wystarczająco solidne w doborze haseł, reprezentatywność ich siatek haseł jest nie najwyższej próby (por. np. Wawrzyńczyk 2009, 2010), dla chronologizatorów leksy-


rzadko sięgając przy datowaniu haseł do dowodów (cytatów) pochodzących z tekstów pozasłownikowych, nie wykorzystuje też wystarczająco źródeł meta in for macy jnych, czasopism, monografii, opracowań itp., w których znajdują się dane doniosłe dla operacji (re)chronologizacyjnych. Liczba tych źródeł jest znaczna i stale rośnie (por. Wawrzyńczyk 2011a: 6-46).

\section{Wykaz skrótów}

CDEP - Rykaczewski E., 1849, A complete dictionary English and Polish, Berlin: B. Behr.

CDPE - Rykaczewski E., 1851, A complete dictionary Polish and English, Berlin: B. Behr.

DNPS - Trojański J. K., 1844-1847, Dokładny niemiecko-polski słownik [...], cz. 1-2, Poznań-Berlin-Bydgoszcz: E. S. Mittler.

DPNS - TrojaŃSKi J. K., 1835-1836, Dokładny polsko-niemiecki stownik [...], cz. 1-2, Poznań-Berlin-Bydgoszcz: E. S. Mittler.

DSWP - RyKaCZeWSKi E., 1856, Dokładny stownik włosko-polski [...], Berlin: B. Behr.

Dykcjonarz - AmszeJewicz M., 1859, Dykcjonarz zawierajacy wyrazy $i$ wyrażenia z obcych języków polskiemu przyswojone [...], Warszawa: A. Gins.

E-XX - Lam S. (red.), 1938, Trzaski, Everta i Michalskiego Encyklopedja XX wieku, Warszawa: Wydawnictwo Trzaski, Everta i Michalskiego.

ESJP - BańKowski A., 2000, Etymologiczny stownik języka polskiego, t. 1-2, Warszawa: Wydawnictwo Naukowe PWN.

ESWO - LAm S. (red.), 1939, Trzaski, Everta i Michalskiego Encyklopedyczny stownik wyrazów obcych [...], Warszawa: Księgarnia Wydawnicza Trzaski, Everta i Michalskiego SA.

EW - LASKowsKi O. (red.), 1931-1939, Encyklopedja wojskowa, t. 1-8, Warszawa: Towarzystwo Wiedzy Wojskowej.

NSPR - ŁUBкоwSKi [imię nieznane], 1836, Nowy stownik polsko-rosyjski, Warszawa: Druk. Banku Polskiego. 
Oczyszciciel - Kortowicz E. S., 1891, Oczyszciciel mowy polskiej czyli słownik obcosłów [...], Poznań: Nakł. Autora.

Przetwory - Przetwory z owoców i warzyw, 1948, Warszawa: Zarząd Główny Związku Samopomocy Chłopskiej Wydział Kobiecy.

SIJP - ARCt M., 1929, Słownik ilustrowany języka polskiego, t. 1-2, wyd. 3, Warszawa: Wydawnictwo M. Arcta.

SJPDor. - DoRoszewski W. (red.), 1958-1969, Słownik języka polskiego, t. 1-11, Warszawa: Wydawnictwo „Wiedza Powszechna”, Państwowe Wydawnictwo Naukowe.

SJPL - Linde S. B., 1807-1814, Słownik języka polskiego, t. 1-6, Warszawa: Druk. XX. Pijarów.

SJPLehr - LeHR-SPŁAwiŃSKi T. (red.), 1938-1939, Słownik języka polskiego, t. 1-2, Warszawa: Księgarnia Wydawnicza Trzaski, Everta i Michalskiego.

SO-JT - JodŁowski S., TAszycki W., 1951, Słownik ortograficzny i prawidła pisowni polskiej, wyd. 2, Wrocław: Zakład Narodowy im. Ossolińskich.

SO-K - Koкоwski W., 1903, Słownik ortograficzny języka polskiego, Warszawa-Łódź: Nakł. L. Fiszera.

SPR - Grekow N. I., Rozwadowska M. F. (red.), 1949, Słownik polsko-rosyjski, Warszawa: Współpraca.

SPRAST - CZEPIELIŃSKI F., 1873, Słownik polsko-rossyjski administracyjno-sqdowo-techniczny, cz. 1-2, wyd. drugie, Warszawa: Druk. J. Goldman.

SWarsz. - KarŁowicz J., KRYŃsKi A. A., NiedźwiedzKi W. (red.), 1900-1927, Słownik języka polskiego, t. 1-8, Warszawa: Nakładem Prenumeratorów / Wydawnictwo Kasy im. Mianowskiego.

SWil. - Zdanowicz A. i in., 1861, Stownik języka polskiego, t. 1-2, Wilno: Wydawnictwo Maurycego Orgelbranda.

SWO-A - ARct M., 1935, Słownik wyrazów obcych. 33000 wyrazów, wyrażeń i przystów cudzoziemskich, wyd. 13, Warszawa: Wyd. M. Arcta.

SWO-R - Rysiewicz Z. (red.), 1958, Słownik wyrazów obcych, wyd. 3, Warszawa: Państwowy Instytut Wydawniczy.

ŹW - Muchliński A., 1858, Źródłosłownik wyrazów [...], Petersburg: Cesarska Akademia Nauk.

ПРС - КРАсный Ю. (ред.), 1931, Польско-русский словарь, Москва: Советская энциклопедия.

РПС - КРАСНЫЙ Ю. (ред.), 1933, Русско-польский словарь, Москва: Советская энциклопедия. 


\section{Bibliografia}

Iwanowski M., 2011, Русизмы в Этимологическом словаре польского языка Анджея Баньковского, Łódź: Instytut Rusycystyki UŁ.

KARAś H., 1996, Rusycyzmy stownikowe w polszczyźnie okresu zaborów, Warszawa: Elipsa.

KoneCZna H., 1936-1937, Wyrazy angielskie w języku polskim, Poradnik Językowy, z. 9, s. 161-170.

MAJER J., 1849, Uwagi w przedmiocie zasad stownictwa lekarskiego [...], Kraków: Druk. UJ.

NowowIEJSKi B., 1996, Zapożyczenia leksykalne z języka niemieckiego w polszczyźnie XIX wieku (na materiale czasopism), Białystok: Dział Wydawnictw Filii UW.

Piotrowski T., 2006, Indeks chronologiczny wyrazów polskich, Poradnik Językowy, z. 9, s. 72-77.

Wawrzyńczyk J., 2009, Autosuplement do Stownika Warszawskiego, Poznań: Sorus.

WAWrzyńczyk J., 2010, Inny „Doroszewski”, Łask: Oficyna Wydawnicza LEKSEM.

WAWRzyŃczyk J., 2011, Stownictwo nowopolskie. Redatacje, Warszawa: BEL Studio.

WaWRzyŃczyK J., 2011a, Stownik bibliograficzny języka polskiego. Wersja przedelektroniczna, t. 8, Warszawa: BEL Studio.

WiERzCHOŃ P., 2008, Fotodokumentacja, chronologizacja, emendacja. Teoria i praktyka weryfikacji materiatu leksykalnego w badaniach lingwistycznych, Poznań: Instytut Językoznawstwa UAM.

WierzchoŃ P., 2010-2011, Depozytorium leksykalne języka polskiego. Nowe fotomateriaty z lat 1901-2010, t. 1-2, Warszawa: BEL Studio.

\section{Dating comments to Etymologiczny slownik jezyka polskiego by Andrzej Bańkowski}

\section{( s u m mary)}

The article contains a critical analysis of the material included in the well-known etymological dictionary of the Polish language by A. Bańkowski. It specifies the dates of appearance in the Polish language of more than 100 lexemes, and provides methodological comments on the process of word-dating. 